\title{
AKTIVITAS ANTIOKSIDAN DAN TABIR SURYA EKSTRAK DAUN AFRIKA (Vernonia amygdalina Del.)
}

\author{
Petrina Febrianti*, Wisnu Cahyo Prabowo, Laode Rijai \\ Laboratorium Penelitian dan Pengembangan FARMAKA TROPIS \\ Fakultas Farmasi Universitas Mulawarman, Samarinda, Kalimantan Timur \\ *Email: petrinafp8@gmail.com
}

\begin{abstract}
ABSTRAK
Daun Afrika (Vernonia amygdalina Del.) adalah salah satu tanaman obat yang secara empiris berpotensi sebagai obat antidiabetes, obat antimalaria dan obat antikanker. Daun Afrika diharapkan dapat menghambat peningkatan radikal bebas yang disebabkan oleh paparan sinar matahari karena Daun Afrika mengandung senyawa flavanoid yang merupakan senyawa antioksidan dan senyawa fotoprotektif. Penelitian ini bertujuan mengetahui nilai $\mathrm{IC}_{50}$ sebagai nilai aktivitas antioksidan Daun Afrika menggunakan metode DPPH, dan juga mengetahui nilai persentase transmisi eritema (\% Te) dan persentase transmisi pigmentasi (\% Tp) ekstrak yang kemudian dimasukkan kedalam kategori profil aktivitas tabir surya. Hasil penelitian menunjukkan ekstrak metanol Daun Afrika memiliki nilai IC $_{50}$ sebesar 175, 021 ppm. Aktivitas tabir surya pada konsentrasi 50 ppm-250 ppm sangat baik digunakan sebagai pencegahan dari pigmentasi kulit dengan profil tabir surya sunblock dan perlindungan ekstra, namun aktivitasnya sangat rendah dalam mencegah terjadinya eritema pada kulit dengan nilai $\%$ Te yang berada di atas $18 \%$.
\end{abstract}

Kata Kunci : Daun Afrika (Vernonia amygdalina Del.), Antioksidan, Tabir Surya

\section{PENDAHULUAN}

Indonesia merupakan salah satu negara yang dilewati garis khatulistiwa sehingga Indonesia memiliki iklim tropis, yang artinya orang Indonesia setiap tahun akan terpapar radiasi sinar matahari lebih banyak dibandingkan di negara-negara yang tidak dilewati garis khatulistiwa. Bahaya dari radiasi sinar matahari berhubungan erat dengan radiasi sinar matahari sebagai penyebab yang memicu adanya radikal bebas dalam tubuh. Oleh karena bahaya dari radiasi sinar matahari terhadap kulit, maka diperlukan adanya senyawa antioksidan dan tabir surya.

Antioksidan bekerja dengan cara mendonorkan satu elektronnya kepada senyawa yang bersifat oksidan sehingga aktivitas senyawa oksidan tersebut bisa 
dihambat. Tabir surya merupakan bahan-bahan kosmetik yang secara fisik atau kimia dapat menghambat penetrasi sinar UV ke dalam kulit. Ada pula tabir surya alami di alam, misalnya senyawa fenolik yang terdapat dalam tumbuhan dan berfungsi melindungi jaringan tanaman terhadap kerusakan akibat radiasi sinar matahari.

Salah satu tanaman yang sering dimanfaatkan sebagai obat adalah Daun Afrika (Vernonia amygdalina Del). Di Indonesia secara empiris bagian daun tanaman ini digunakan sebagai obat antidiabetes, obat antimalaria dan obat antikanker. Berdasarkan skrining fitokimia yang dilakukan di Uganda diketahui bahwa Daun Afrika positif mengandung alkaloid, saponin, tannin, seskueterpen lakton, triterpenoid, asam amino, flavonoid, terpenoid, and kardiotonik. Beberapa penelitian lainnya juga menunjukkan adanya kandungan senyawa fenolik termasuk flavanoid yang terdapat dalam Daun Afrika (Vernonia amygdalina Del.), maka perlu dilakukan pengujian terhadap aktivitas antioksidan dan aktivitas sebagai tabir surya Daun Afrika.

\section{METODE PENELITIAN}

\section{Bahan}

Bahan yang digunakan: simplisia daun afrika, pelarut metanol, dan serbuk DPPH.

\section{Peralatan}

Alat-alat yang digunakan: seperangkat alat gelas yang ada di laboratorium, rotary evaporator, spektrofotometri UV-Vis double beam (Dynamica Halo DB20S), dan timbangan analitik.

\section{PROSEDUR}

\section{Pengumpulan dan Penyiapan Sampel}

Sampel segar daun afrika dikumpulkan, disortasi basah dan dicuci dengan air mengalir. Sampel kemudian dirajang setelah itu dikeringkan dalam ruangan yang terlindung matahari. Setelah sampel kering selanjutnya disortasi kering hingga diperoleh simplisia kering. 


\section{Ekstraksi}

Simplisia daun afrika diekstraksi menggunakan metode maserasi. Simplisia daun afrika dimasukkan ke dalam wadah maserasi dan direndam selama 3 hari sambil sesekali diaduk kemudian filtrat disaring. Residu yang didapatkan dimaserasi kembali hingga filtrat yang didapatkan bening. Filtrat yang terkumpul dipekatkan dengan menggunakan alat rotary evaporator sehingga didapatkan ektrak ketal.

\section{Pengujian Aktivitas Antioksidan}

Serbuk DPPH ditimbang sebanyak $4 \mathrm{mg}$ untuk dilarutkan dalam $100 \mathrm{~mL}$ metanol di dalam labu ukur gelap atau labu ukur berwarna coklat, sehingga didapatkan larutan DPPH dengan konsentrasi 40 ppm (part per million) yang digunakan pada pengujian. Larutan disimpan pada tempat tertutup rapat dan terlindung dari cahaya.

Ekstrak metanol daun afrika dibuat ke dalam 5 seri konsentrasi yaitu 50, 100, 150, 200 dan 250 ppm. Masing-masing larutan uji diambil 2 mL ekstrak kemudian ditambahkan dengan $2 \mathrm{~mL}$ larutan DPPH 40 ppm ke dalam tabung reaksi bertutup, dilakukan juga pengujian blanko. Campuran ini dihomogenkan dengan menggunakan vorteks dan dibiarkan di tempat gelap pada suhu kamar selama 30 menit. Kemudian diukur absorbansinya pada panjang gelombang $514 \mathrm{~nm}$. Dari data absorbansi ini dapat ditentukan \% Inhibisi ekstrak daun afrika dengan rumus :

$\%$ inhibisi $=\frac{\text { A blanko }- \text { A sampel }}{\text { A blanko }} \times 100 \%$

Nilai IC $_{50}$ dihitung dengan menggunakan rumus persamaan regresi yang kemudian dikategorikan ke dalam kategori tingkat kekuatan antioksidan (Tabel 1).

Tabel 1. Tingkat kekuatan antioksidan [6].

\begin{tabular}{ll}
\hline Intensitas & Nilai $\mathrm{IC}_{50}$ \\
\hline Sangat Kuat & $<50 \mathrm{ppm}$ \\
Kuat & $50-100 \mathrm{ppm}$ \\
Sedang & $101-250 \mathrm{ppm}$ \\
Lemah & $250-500 \mathrm{ppm}$ \\
Tidak aktif & $>500 \mathrm{ppm}$ \\
\hline
\end{tabular}




\section{Pengujian Aktivitas Tabir Surya}

Ekstrak daun afrika dibuat ke dalam 5 seri konsentrasi yaitu 50, 100, 150, 200, dan 250 ppm. Masing-masing konsentrasi diukur absorbansinya dengan menggunakan spektrofotometer UV-Vis pada panjang gelombang 292,5-372,5 nm dengan interval $5 \mathrm{~nm}$ (3 kali replikasi). Dari nilai absorbansi yang didapatkan, maka dapat dihitung nilai transmisi ekstrak dengan persamaan:

$A=-\log T$

$\mathrm{A}=$ Absorbansi sampel

$\mathrm{T}=$ Transmisi

Setelah nilai transmisi diketahui maka dapat dihitung nilai persentase transmisi eritema dan nilai persentase transmisi pigmentasi menggunakan persamaan :

$$
\begin{aligned}
& \% \mathrm{Te}=\frac{\sum(\mathrm{T} \times \mathrm{Fe})}{\sum \mathrm{Fe}} \times 100 \% \\
& \% \mathrm{Tp}=\frac{\sum(\mathrm{T} \times \mathrm{Fp})}{\sum \mathrm{Fp}} \times 100 \%
\end{aligned}
$$

Keterangan:

$\% \mathrm{Te}=$ persentase transmisi eritema

$\% \mathrm{Tp}=$ persentase transmisi pigmentasi

$\mathrm{T}=$ nilai Transimisi

$\mathrm{Fe} \quad=$ nilai fluks eritema

$\mathrm{Fp} \quad=$ nilai fluks pigmentasi

\section{Penentuan Profil Tabir Surya}

Profil tabir surya ekstrak Daun Afrika didasarkan pada hasil perhitungan nilai persentase transmisi eritema (\% Te) dan nilai persentase transmisi pigmentasi (\% Tp) yang telah diperoleh pada uji aktivitas tabir surya. Nilai \% Te dan \% Tp masingmasing variasi konsentrasi dikategorikan ke dalam penilaian aktivitas tabir surya (Tabel 2). 
Tabel 2. Kategori Profil Tabir Surya [2].

\begin{tabular}{ccc}
\hline Kategori & $\% \mathrm{Te}$ & $\% \mathrm{Tp}$ \\
\hline Sunblock & $<1$ & $3-40$ \\
Proteksi ekstra & $1-6$ & $42-86$ \\
Sutan standar & $6-12$ & $45-86$ \\
Fast tanning & $10-18$ & $45-86$ \\
\hline
\end{tabular}

\section{HASIL DAN PEMBAHASAN}

\section{Aktivitas Antioksidan Ekstrak Daun Afrika}

Aktivitas antioksidan yang terkandung dalam ekstrak daun afrika ditentukan dengan metode DPPH. Metode DPPH dipilih karena metode ini sederhana, mudah, cepat, dan peka serta memerlukan sedikit sampel. Prinsip uji DPPH adalah penghilangan warna untuk mengukur kapasitas antioksidan yang langsung menjangkau radikal DPPH dengan pemantauan absorbansi pada panjang gelombang $517 \mathrm{~nm}$ menggunakan spektrofotometer. Radikal DPPH dengan nitrogen organik terpusat adalah radikal bebas stabil dengan warna ungu gelap yang ketika direduksi menjadi bentuk nonradikal oleh antioksidan menjadi warna kuning.

Hasil penelitian antioksidan yang ditunjukkan dalam Gambar 1. menunjukkan $\%$ aktivitas antioksidan atau \% inhibisi dari ekstrak daun afrika dalam menghambat aktivitas oksidan pada DPPH. Nilai konsentrasi dengan nilai \% aktivitas antioksidan terbaik ekstrak daun afrika yaitu pada konsentrasi $250 \mathrm{ppm}$ dengan $\%$ aktivitas antioksidan sebesar $70 \%$. 


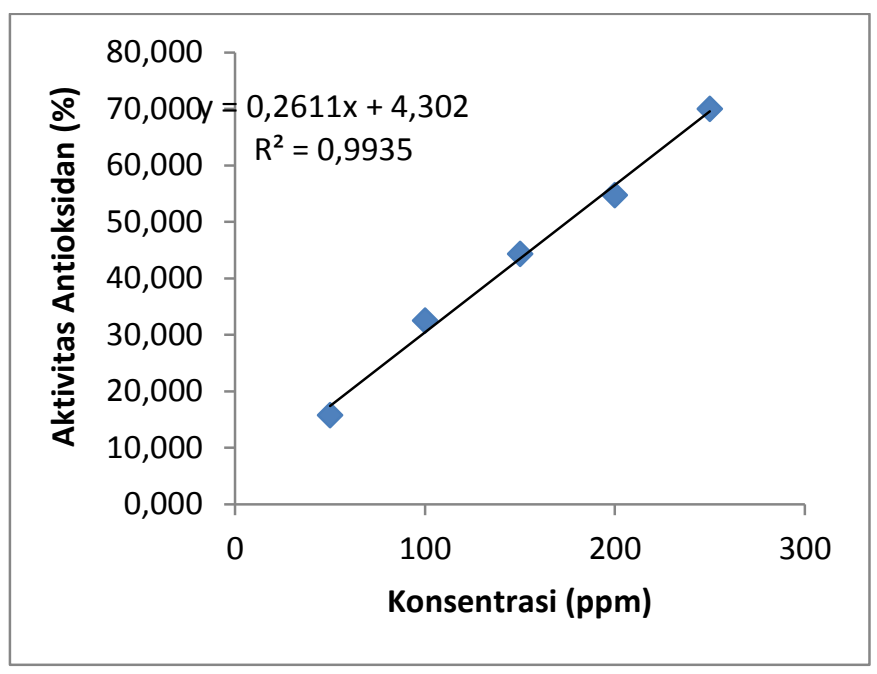

Gambar 1. Aktivitas antioksidan ekstrak metanol Daun Afrika

Parameter yang digunakan untuk menerangkan hasil penentuan aktivitas antioksidan adalah $\mathrm{IC}_{50}$. $\mathrm{IC}_{50}$ atau inhibitory concentration $50 \%$ adalah konsentrasi larutan contoh yang menyebabkan berkurangnya aktivitas DPPH sebesar 50\% [7]. $\mathrm{IC}_{50}$ didapat dari kurva hubungan antara persen penangkapan radikal bebas dengan konsentrasi $(\mathrm{ppm})$ menggunakan regresi linier. Prinsip metode yang digunakan menyatakan bahwa semakin kecil konsentrasi larutan contoh untuk mengurangi aktivitas DPPH sebesar 50\% maka aktivitas antioksidannya semakin kuat.

Dari hasil penelitian yang telah dilakukan maka dapat dihitung nilai IC50 ekstrak daun afrika sehingga didapatkan nilai IC50 sebesar 175, 021 ppm. Nilai $\mathrm{IC}_{50}$ ini kemudian dapat digolongkan sebagai senyawa antioksidan dengan tingkat sedang yang artinya senyawa antioksidan yang terkandung dalam daun afrika sudah cukup baik dalam menghambat kerja radikal bebas dalam DPPH, namun dalam konsentrasi kecil belum dapat menghambat 50\% aktivitas radikal bebas DPPH.

\section{Aktivitas Tabir Surya Ekstrak Daun Afrika}

Aktivitas tabir surya ekstrak daun afrika dilihat melalui profil tabir surya ekstrak daur afrika yang dibagi ke dalam empat kategori profil tabir surya. Profil tabir surya adalah pengkatagorian yang dilakukan sehingga dapat diketahui aktivitas ekstrak dalam memproteksi atau melindungi kulit dari radiasi sinar matahari yaitu sinar UV A (320-400 nm) dan sinar UV B (290-320 nm). 
Penelitian yang dilakukan untuk mengetahui aktivitas tabir surya ekstrak yaitu menggunakan pengujian secara in vitro yaitu menggunakan spektofotometer UVVis. Nilai absorbansi yang didapatkan hasil pengukuran masing-masing konsentrasi dikonversi menjadi nilai transmitan, dimana semakin kecil nilai transmitan maka semakin banyak sinar yang diserap oleh sampel sehingga aktivitas tabir surya semakin baik.

Tabel 3. Profil Tabir Surya Ekstrak Daun Afrika (Vernonia amygdalina Del.)

\begin{tabular}{cccc}
\hline $\begin{array}{c}\text { Konsentrasi } \\
\text { Sampel (ppm) }\end{array}$ & $\% \mathrm{Te}$ & $\% \mathrm{Tp}$ & Kategori \\
\hline 50 & 76.064 & 76.710 & Proteksi ekstra \\
100 & 62.403 & 63.446 & Proteksi ekstra \\
150 & 48.206 & 49.554 & Proteksi ekstra \\
200 & 36.316 & 37.676 & Sunblock \\
250 & 27.506 & 28.903 & Sunblock \\
\hline
\end{tabular}

Hasil penelitian menunjukkan bahwa pada ekstrak metanol daun afrika sangat baik digunakan sebagai pencegahan dari pigmentasi kulit namun aktivitasnya sangat rendah dalam mencegah terjadinya eritema pada kulit dengan nilai \% $\mathrm{Te}$ yang berada di atas 18\% (Tabel 3).

Nilai persentase transmisi eritema (\%Te) adalah nilai yang menggambarkan kemampuan suatu molekul kimia untuk memproteksi kulit dari sinar UV yang dapat menyebabkan eritema yaitu banyaknya jumlah energi sinar UV yang diteruskan pada radiasi UV B (292,5-337,5 nm). Eritema adalah kemerah-merahan pada kulit yaitu proses inflamasi yang terjadi 2-3 jam setelah sengatan surya, berkembang dalam 10-24 jam akibat dari kerusakan sel yang menyebabkan terlepasnya zat mirip/histamin, sehingga terjadi pelebaran pembuluh darah dan eritema [5]. Dari hasil peneliitian yang telah dilakukan menunjukkan ekstrak daun afrika pada semua seri konsentrasi masih dapat meneruskan sinar UV B secara total ke kulit sehingga ekstrak pada konsentrasi 50 hingga 250 ppm belum dapat melindungi kulit dari eritema akibat paparan sinar UV B.

Nilai persentase transmisi pigmentasi (\% $\%$ pp) adalah nilai yang menggambarkan kemampuan suatu molekul kimia untuk memproteksi kulit dari 
sinar UV yang dapat menyebabkan pigmentasi yaitu banyaknya jumlah energi sinar UV yang diteruskan pada radiasi UV A (322,5-372,5 nm). Pigmentasi adalah perubahan warna kulit yang lebih gelap akibat pajanan UV dapat teramati dalam waktu 24 jam dan puncaknya pada hari ke 8. Pigmentasi tertunda ini akibat peningkatan produksi pigmen melanin dan menyebabkan peningkatan ketebalan epidermis [5]. Dari hasil peneliitian yang telah dilakukan menunjukkan ekstrak daun afrika pada semua seri konsentrasi pada konsentrasi 200-250 ppm dapat memproteksi secara total paparan sinar UV A sedangkan pada konsentrasi lainnya masih dapat meneruskan sinar UV A.

\section{Penentuan Profil Tabir Surya Ekstrak}

Penentuan profil tabir surya yaitu berdasarkan nilai \%Te dan \% Tp nya, profil tabir surya dibagi kedalam empat kelompok yaitu sunblock, proteksi ekstra, sutan standar, dan fast tanning. Dari hasil pengukuran \% Te dan \% Tp ekstrak daun afrika, ekstrak daun afrika pada seri konsentrasi 50-150 ppm masuk dalam kategori proteksi ekstra dan pada konsentrasi 200-250 ppm ke dalam kategori sunblock.

Proteksi ekstra adalah kemampuan ekstrak sebagai bahan tabir surya yang memberikan perlindungan terhadap eritema dengan mengabsorbsi kurang dari 85 \% radiasi sinar UV B serta mencegah terjadinya pigmentasi. Kemampuan bahan pada kategori ini akan menghasilkan sedikit eritema tanpa rasa sakit [11]. Kategori proteksi ekstra tabir surya digunakan untuk melindungi jenis kulit yang sensitif [4].

Sunblock merupakan kemampuan ekstrak untuk memproteksi secara total kulit yang sangat sensitif terhadap sinar UV A dan UV B [4]. Aktivitas tabir surya ekstrak sebagai sunblock mampu menghalangi paparan sinar UV ke dalam kulit sehingga melindungi kulit dari terjadinya eritema dan pigmentasi.

Ekstrak daun afrika dapat digunakan sebagai tabir surya karena adanya kandungan berupa senyawa fenolik. Senyawa tersebut memiliki ikatan terkonjugasi yang dapat beresonansi ketika terkena sinar ultraviolet (UV) sehingga bersifat photoprotective [8].

\section{KESIMPULAN}

Hasil penelitian menunjukkan ekstrak metanol Daun Afrika memiliki nilai $\mathrm{IC}_{50}$ sebesar 175, $021 \mathrm{ppm}$. Dari penelitian ini juga menunjukkan bahwa aktivitas 
tabir surya pada konsentrasi 50 ppm-250 ppm sangat baik digunakan sebagai pencegahan dari pigmentasi kulit dengan profil tabir surya sunblock dan perlindungan ekstra, namun aktivitasnya sangat rendah dalam mencegah terjadinya eritema pada kulit dengan nilai \% Te yang berada di atas $18 \%$.

\section{DAFTAR PUSTAKA}

Adiukwu, P.C. et al. 2011. Pharmacognostic, Antiplasmodial and Antipyretic Evalution of The Aqueous Extract of Vernonia amygdalina Leaf. International Journal of Biological and Chemical Science

Balsam, M.S. 1972. Cosmetic Science and Technology Second Edition. Jhon Willy and Son, Inc. London.

Bendra, Atika. 2012. Uji Aktivitas Antioksidan Ekstrak Daun Premna oblongata Miq. Dengan Metode DPPH dan Identifikasi Golongan Senyawa Kimia dari Fraksi Teraktif. Skripsi. Program Studi Ekstensi, Fakultas Matematika dan Ilmu Pengetahuan Alam, Universitas Indonesia, Depok.

Cumpelik, B. S. 1972. Analitical Procedures and Evaluation of Sunscreens. Journal of the Society of Cosmetics Chemistry. 25. (3) 333- 345. 7.

Hasanah, Siti. 2015. Profil Tabir Surya Ekstrak dan Fraksi Daun Pidada Merah (Sonneratia caseolaris L.). Skripsi. Fakultas Farmasi Universitas Mulawarman. Samarinda

Jun, M.H.Y., Yu., J., Fong, X., Wan, C.S, Yang, C.T. and Ho. 2003. Comparison of antioxidant activities of isoflavones from kudzu root (Pueraria labata Ohwl). J. Food Sci. Institute of Technologist. 68: 2117-2122

Molyneux P. 2004. The use of stable free radical diphenylpicryl hydrazil (DPPH) for estimating antioxidant activity. J. Sci. Technol.: 211-219.

Prasiddha, Ismizana J. 2016. Potensi Senyawa Bioaktif Rambut Jagung (Zea mays L.) Untuk Tabir Surya Alami : Kajian Pustaka. Jurnal Pangan dan Agroindustri. Vol 4 No 1

Shovyana, Hidayatul. 2013. Stabilitas Fisik dan Aktivitas Krim W/O Ekstrak Etanolik Buah Mahkota Dewa (Phaleria macrocarpha (scheff.) Boerl) Sebagai Tabir Surya. Traditional Medica Journal Volume 18 Nomor 2.

Widyaningsih, Wahyu. 2010. Uji Aktivitas Antioksidan Ekstrak Etanol Daun Dewa (Gynura procumbens) Dengan Metode DPPH (1,1-difenil-2-pikrilhidrazil). Prosiding Seminar Nasional Kosmetika Alami, Fakultas Farmasi Universitas Ahmad Dahlan, Yogyakarta.

Wilkinson, J. B dan Moore, R. J. 1982. Harry's Cosmeticology (7th edition). Chemical Publishing Company. New York. 